Article

\title{
Sodium Energetic Cycle in the Natronophilic Bacterium Thioalkalivibrio versutus
}

\author{
Maria S. Muntyan ${ }^{1, *(\mathbb{D}}$, Mikhail B. Viryasov ${ }^{1}$, Dimitry Y. Sorokin ${ }^{2,3}{ }^{(-D}$ and Vladimir P. Skulachev ${ }^{1}$ \\ 1 Belozersky Institute of Physico-Chemical Biology, Lomonosov Moscow State University, Leninskie Gory, \\ 119991 Moscow, Russia; viryasov@genebee.msu.ru (M.B.V.); skulach@genebee.msu.ru (V.P.S.) \\ 2 Winogradsky Institute of Microbiology, Federal Research Centre of Biotechnology, Russian Academy of \\ Sciences, 117312 Moscow, Russia; soroc@inmi.ru \\ 3 Department of Biotechnology, Delft University of Technology, 2628 BC Delft, The Netherlands \\ * Correspondence: muntyan@genebee.msu.ru
}

Citation: Muntyan, M.S.; Viryasov, M.B.; Sorokin, D.Y.; Skulachev, V.P. Sodium Energetic Cycle in the Natronophilic Bacterium Thioalkalivibrio versutus. Int. J. Mol. Sci. 2022, 23, 1965. https://doi.org/ $10.3390 /$ ijms 23041965

Academic Editors: Vitaliy Borisov and Sergey Siletsky

Received: 31 December 2021

Accepted: 8 February 2022

Published: 10 February 2022

Publisher's Note: MDPI stays neutral with regard to jurisdictional claims in published maps and institutional affiliations.

Copyright: (C) 2022 by the authors. Licensee MDPI, Basel, Switzerland. This article is an open access article distributed under the terms and conditions of the Creative Commons Attribution (CC BY) license (https:// creativecommons.org/licenses/by/ $4.0 /)$.

\begin{abstract}
As inhabitants of soda lakes, Thioalkalivibrio versutus are halo- and alkaliphilic bacteria that have previously been shown to respire with the first demonstrated $\mathrm{Na}^{+}$-translocating cytochrome- $c$ oxidase (CO). The enzyme generates a sodium-motive force $(\Delta s)$ as high as $-270 \mathrm{mV}$ across the bacterial plasma membrane. However, in these bacteria, operation of the possible $\Delta s$ consumers has not been proven. We obtained motile cells and used them to study the supposed $\mathrm{Na}^{+}$energetic cycle in these bacteria. The resulting motility was activated in the presence of the protonophore 2-heptyl-4-hydroxyquinoline $\mathrm{N}$-oxide (HQNO), in line with the same effect on cell respiration, and was fully blocked by amiloride-an inhibitor of $\mathrm{Na}^{+}$-motive flagella. In immotile starving bacteria, ascorbate triggered CO-mediated respiration and motility, both showing the same dependence on sodium concentration. We concluded that, in T. versutus, $\mathrm{Na}^{+}$-translocating $\mathrm{CO}$ and $\mathrm{Na}^{+}$-motive flagella operate in the $\mathrm{Na}^{+}$energetic cycle mode. Our research may shed light on the energetic reason for how these bacteria are confined to a narrow chemocline zone and thrive in the extreme conditions of soda lakes.
\end{abstract}

Keywords: flagellar motor; $\mathrm{Na}^{+}$-motive cytochrome oxidase; alkaliphiles; $\mathrm{Na}^{+}$energetic cycle; sodium-motive force

\section{Introduction}

Recent studies of new extreme habitats of living organisms have led to the discovery of new subdivisions of bacteria and archaea, and significantly expanded knowledge of the possible limits of life [1,2]. Following this, new data on the energetics [3-13] and biocatalysis [14-16] in organisms capable of living in extreme conditions have been disclosed. Soda lakes belong to such areas, being characterized by a combination of several extremes [17]. Bacteria of the genus Thioalkalivibrio-belonging to the class Gammaproteobacteria, and distantly related to anoxygenic purple sulfur bacteria of the genus Ectothiorhodospira-are common inhabitants of soda lakes [18-25], and belong to the double-extremophilic bacteria [26]. Among them is the strain Thioalkalivibrio versutus, which has adapted to thriving in soda brines characterized by both strong alkalinity ( $\mathrm{pH}$ up to 11) and high salinity, with almost saturating salt concentrations (up to $4 \mathrm{M} \mathrm{Na}^{+}$) [27]. The strain is obligately aerobic, as described earlier. A surprising adaptation of Thioalkalivibrio strains to life in extreme alkaline conditions with saturating sodium concentrations is the use of a sodium pump at the terminus of their respiratory chain $\left(\mathrm{Na}^{+}\right.$-motive cytochrome-c oxidase) $[28,29]$. This is the first $\mathrm{Na}^{+}$-motive oxygen-reducing enzyme proven to operate in living organisms. Long before the discovery of these bacteria, the emergence of such a sodium pump was predicted to counteract the low proton-motive force $(\Delta p)$ on membranes of alkaliphiles in alkaline media [30-32], but only 30 years later was the sodium pump discovered [29]. Our data showed that, indeed, in T. versutus cells the $\Delta p$ is as low as $-80 \mathrm{mV}$ [33]. According 
to Guffanti and Krulwich, as was shown in alkaliphilic Bacillus strains, this value is not enough to drive ATP synthesis $[34,35]$. At the same time, in T. versutus, operation of the $\mathrm{Na}^{+}$-motive cytochrome- $c$ oxidase enables the maintenance of a high negative electrical potential on their membranes [33], which is even higher than that shown in many alkaliphiles [35]. Direct methods have shown that the described sodium pump generates a high sodium-motive force ( $\Delta s$ [36]) across the bacterial cytoplasmic membranes [29], and has properties inherent in alkaliphilic proteins [37].

According to the genomic databases, in Thioalkalivibrio representatives, a possible presence of $\Delta s$ consumers can be predicted; among such $\Delta s$ consumers are secondary $\mathrm{Na}^{+}$-transporters and $\mathrm{Na}^{+}$-type flagella [38]. However, in T. versutus, the functioning of the sodium energetic cycle composed of a $\Delta s$ generator and a $\Delta s$ consumer has not been experimentally proven. Previously, we have undertaken the first steps towards achieving bacterial motility [39]. In the present study, we describe the modified procedure for the selection of stable motile bacterial cells suitable for the study of bioenergetic characteristics and, using inhibitor analysis, experimentally ascertain the $\mathrm{Na}^{+}$type of the flagellar motor. Our findings allow us to verify in T. versutus the functioning of the sodium energetic cycle, which consists of a $\Delta s$ generator and a $\Delta s$ consumer.

\section{Results and Discussion}

Previously, heme of types B, D, and $\mathrm{O}$ was found in the cells of several different Thioalkalivibrio strains $[40,41]$, indicating the possibility of induction of different types of oxygen reductase enzymes in representatives of this genus under different conditions. However, the membranes of the Thioalkalivibrio versutus strain grown in this work at the optimal $\mathrm{pH}$ ( $\mathrm{pH} 10.2$ ) (Figure 1a) contained only cytochromes $c$ and $b$-detected spectrally as published earlier [29] — and heme B, according to the HPLC analysis (Figure 1b). Thus, the heme and cytochrome composition of the membranes, as well as the presence of only $\mathrm{Na}^{+}$-dependent components on respiration curves in the $\mathrm{pH}$ range $7.5-10.5$, similar to that shown earlier (see Figure 1 in [29]), indicated that under the conditions used the previously described $\mathrm{Na}^{+}$-motive $c b b_{3}$ oxidase [29] served as the main terminal oxidase in the strain.

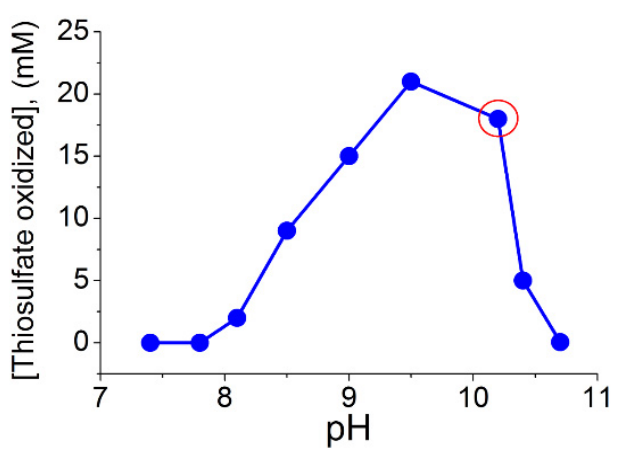

(a)

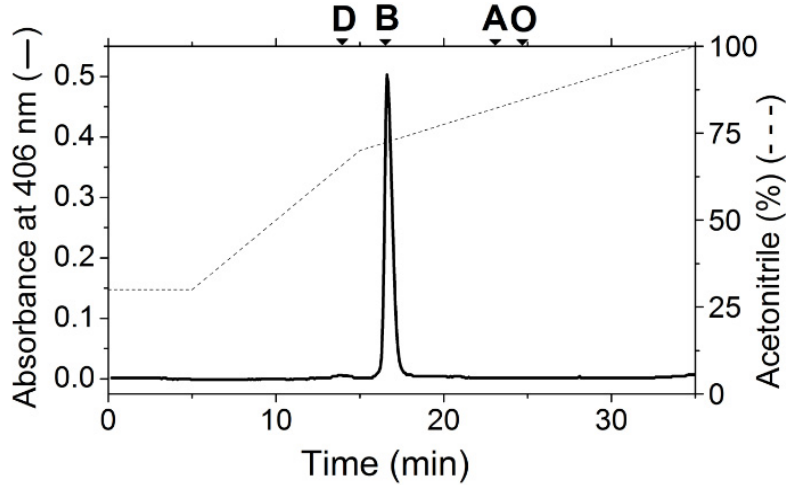

(b)

Figure 1. Thioalkalivibrio versutus batch culture characteristics: (a) $\mathrm{pH}$ profile for substrate consumption by T. versutus measured in batch culture. Each point corresponds to independent cultivation at constant $\mathrm{pH}$. The red circle depicts cultivation conditions used in the study, and for the isolation of T. versutus from a swimming culture. (b) Heme profile of the T. versutus membranes, isolated from the cells cultured at $\mathrm{pH} 10.2$ under oxygen-limited conditions. A ruler with the elution times for standard heme D, B, A, and $\mathrm{O}$ is shown at the top of the graph. Elution was carried out with a gradient of acetonitrile in water containing $0.05 \%$ trifluoroacetic acid (dashed line).

The $T$. versutus strain is obligately aerobic, and can derive energy from aerobic oxidation of reduced sulfur compounds [27]. In our experiments, thiosulfate was used as an energy source. To activate motility of the cells that were initially motionless, we used 
a semi-liquid medium containing $0.3 \%$ agarose, placed in Petri dishes. Some time after planting the inoculum in the center of the Petri dishes, expanding whitish swimming rings appeared on the surface of the medium (Figure 2a-c).

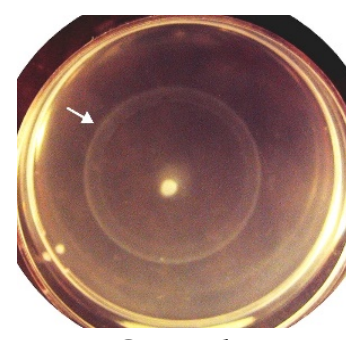

Control

(a)

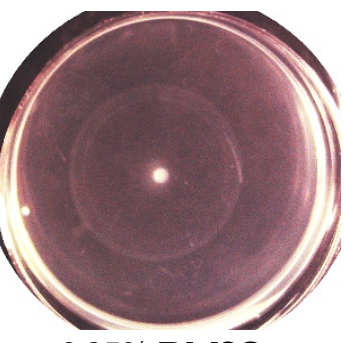

$0.25 \%$ DMSO

(b)

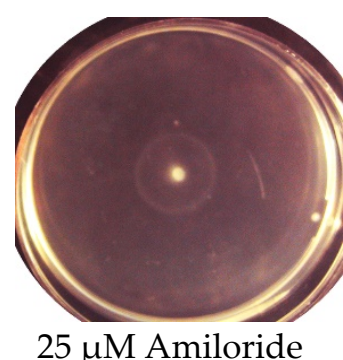

(c)

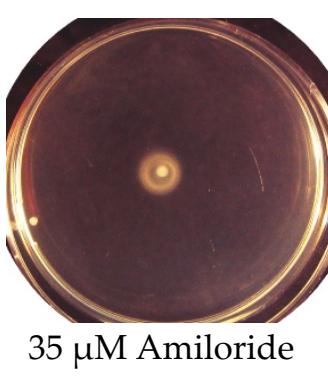

(d)

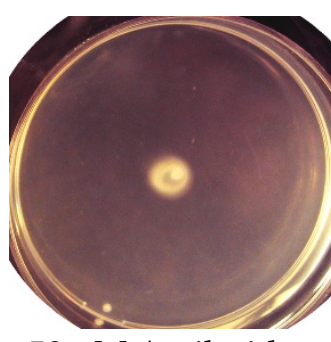

$50 \mu \mathrm{M}$ Amiloride

(e)

Figure 2. Formation of the bacterial swimming rings by the passaged T. versutus cells: (a-e) T. versutus formed bacterial swimming rings (white arrow indicates such a ring on the left panel), seen as radially widening whitish opalescent circles on the surface of the semi-liquid medium in Petri dishes (the photos demonstrate a typical picture $23 \mathrm{~h}$ after inoculation). Visible as bright white dots in the center of each Petri dish are unpassaged cells (for details, see Section 3).

Microscopic examination showed that the cells taken from the swimming rings became motile. The ability of T. versutus cells to acquire motility in a semi-liquid medium depended on the thiosulfate concentration in the medium (Figure 3a). The absence of a lag phase before the start of movement was observed at $1.5 \mathrm{mM}$ thiosulfate. An increase in the thiosulfate concentration to $2.5 \mathrm{mM}$ and $30 \mathrm{mM}$ led to a progressive delay in the ability of cells to move. Motile cells sampled from the periphery of the rings had monopolar flagellation and a single flagellum (Figure $3 b$ ).

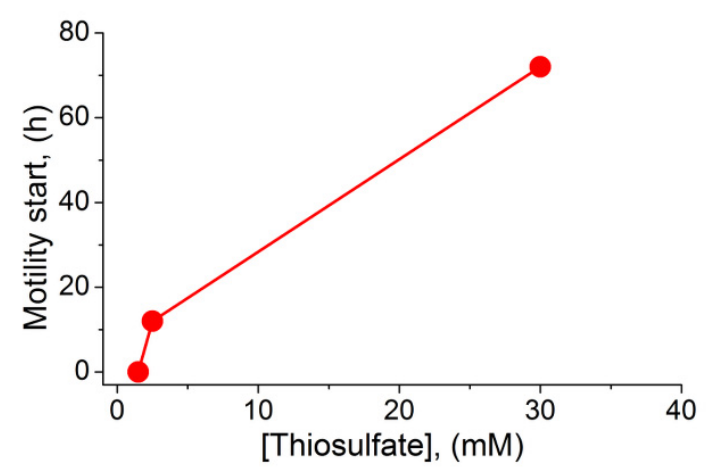

(a)

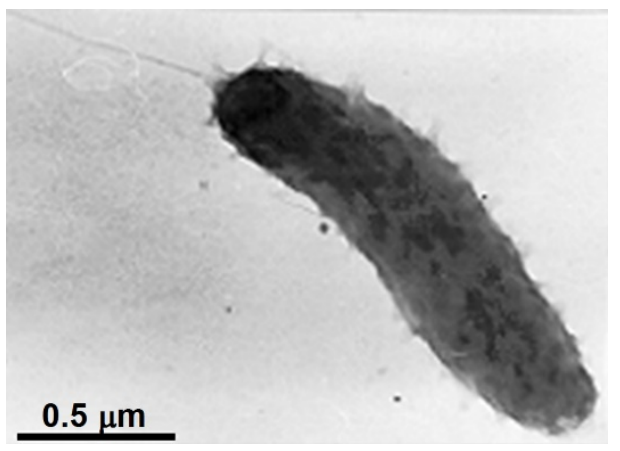

(b)

Figure 3. Activation of T. versutus cell motility: (a) Dependence of the start of motility on the concentration of the growth substrate. (b) Electron micrograph of a flagellum-bearing T. versutus cell stained with $1 \%$ uranyl acetate.

To determine the type of flagellar motor, we used amiloride-an inhibitor of $\mathrm{Na}^{+} / \mathrm{H}^{+}$ antiporters and $\mathrm{Na}^{+}$channels of many organisms [42], which is also known as a specific inhibitor of the $\mathrm{Na}^{+}$-type flagellar motor [43]. According to Atsumi et al., at alkaline $\mathrm{pH}$, amiloride interfered with the growth of some Bacillus and Vibrio alkaliphilic species in solid and semi-liquid media [44]. In our experiments, amiloride at concentrations no higher than $50 \mu \mathrm{M}$ did not affect the growth of T. versutus culture, and was used in further experiments at these low concentrations. Testing in semi-liquid media showed that amiloride at low concentrations blocked the expansion of swimming rings (Figure 2c-e). Thus, it could be assumed that $T$. versutus motility is provided by $\mathrm{Na}^{+}$-motive flagella. However, it was 
previously noted that, in contrast to semi-liquid media-in which amiloride in concentrations of tens of micromoles can inhibit bacterial growth-liquid media make it possible to study the effects of amiloride at higher concentrations [44]. For a more detailed study of amiloride's effects, we used microscopy to analyze the cell motility speed in a liquid medium in a Goryaev chamber. For this, the cells selected for maximal swimming speed in a semi-liquid medium were collected and studied when the substrate was washed out. The motility was initiated by adding thiosulfate (Figure 4a) or a cytochrome oxidase substrate (ascorbate) (Figure 4b). Thiosulfate-initiated cell respiration remained constant with increasing amiloride concentration (Figure 4a, lower panel); this indicates that amiloride had no effect on the oxygen-reducing $\Delta s$ generator cytochrome oxidase. On the other hand, in both semi-liquid (Figure 4a, upper panel) and liquid media (Figure 4b), amiloride suppressed bacterial motility, albeit with different efficiency. While the half-maximal inhibitory effect was comparable in both variants- $\mathrm{I}_{50} 25 \mu \mathrm{M}$ and $30 \mu \mathrm{M}$, respectively-complete inhibition of motility in a semi-liquid medium was achieved at a significantly lower concentration of amiloride (50 $\mathrm{MM}$, versus almost $1 \mathrm{mM}$ in a liquid medium). In both cases, dimethyl sulfoxide (DMSO) free of amiloride (used as a solvent for amiloride in other experiments) did not affect motility (Figures $2 \mathrm{~b}$ and $4 \mathrm{~b}$ ). The picture of the dependence of T. versutus motility on amiloride concentration in a liquid medium coincides with the previously published data for Vibrio alginolyticus [45], and confirms that the cells use the sodium flagellar motor.

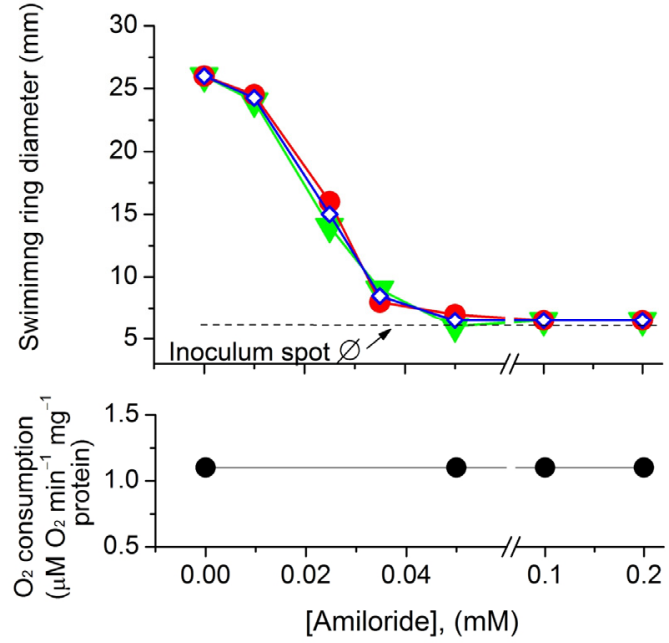

(a)

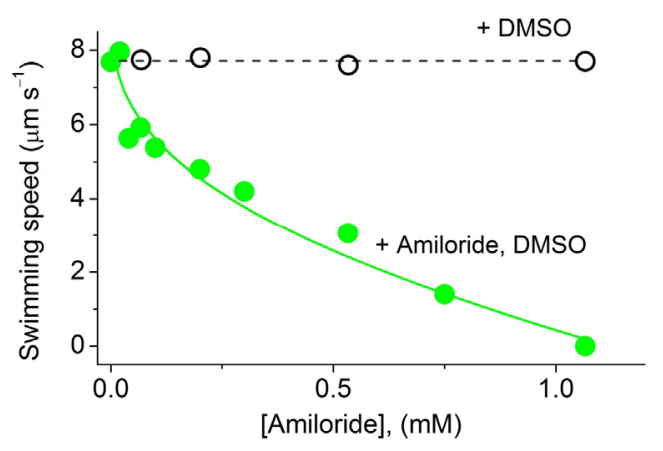

(b)

Figure 4. Effect of amiloride on the motility of T. versutus cells: (a) Dependence of the swimming rings' diameter (upper panel) and cell respiratory rate (lower panel) on amiloride concentration. For motility, a semi-liquid medium supplied with $1.5 \mathrm{mM}$ thiosulfate as an energy substrate was used. The diameters shown in the graph were recorded $19 \mathrm{~h}$ after the start of three independent experiments. The results of each experiment are marked with closed red circles, closed green triangles, or open blue diamonds. At the bottom of the upper panel, the level of inoculum spots' diameter is indicated (dashed line). (b) Dependence of the cell motility speed in a liquid medium on amiloride concentration (closed green circles). The cell motility was examined in a Goryaev chamber, using transmitted light

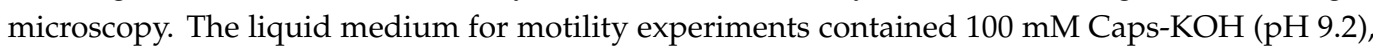
$0.6 \mathrm{M} \mathrm{KCl}, 10 \mathrm{mM} \mathrm{NaCl}$, and $10 \mathrm{mM}$ ascorbate as an energy substrate. The graph data are the average of three independent experiments. In each independent experiment, the swimming speed value at each indicated concentration of amiloride is the average of 40-45 individual measurements.

To verify the effect of sodium ions on cell motility, we used bacterial cells washed to remove sodium and then placed in a liquid medium free of sodium and respiratory substrates. After one day of starvation, such bacterial cells became motionless. The motility of the cells was recovered upon the addition of $\mathrm{NaCl}$, achieving final concentrations of 
1-20 $\mathrm{mM}$ in the presence of ascorbate in the medium (Figure 5). The effect of sodium was specific to monovalent cations, since neither potassium chloride nor lithium chloride restored bacterial motility—similar to findings for the alkaliphilic Bacillus YN-1 [46]. The dependence of the motility and respiratory activity of T. versutus cells on sodium concentration, as well as their sodium specificity, proved to be the same, which could indicate that the $\mathrm{Na}^{+}$-motive cytochrome oxidase and $\mathrm{Na}^{+}$-type flagella operated in one and the same mode of the $\mathrm{Na}^{+}$energetic cycle. Interestingly, the effect of sodium chloride in nearly the same concentration range was observed on the motility of Vibrio alginolyticus 1854, Vibrio cholerae VIO5 [47], Vibrio alginolyticus Nap1 [48], Vibrio parahaemolyticus [45], and an alkaliphilic Bacillus_B. firmus RAB [46].

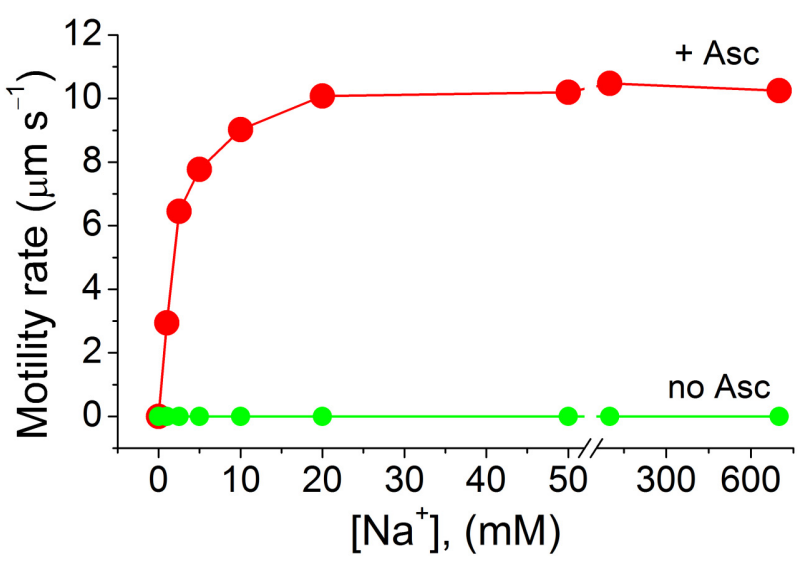

Figure 5. Motility recovery of the initially motionless T. versutus cells in a liquid medium; $10 \mathrm{mM}$ potassium ascorbate was used as a substrate. Concentration of sodium in the bacterial suspension was varied by the addition of small aliquots of the incubation medium, containing $4 \mathrm{M} \mathrm{NaCl}$ (for details, see Section 3).

However, such a flagellar motor could be started either directly by $\Delta s$-generated by means of a primary $\mathrm{Na}^{+}$pump, as in Vibrio species at alkaline $\mathrm{pH}$ [49]—or indirectly, when $\Delta p$, generated by a primary $\mathrm{H}^{+}$pump at neutral $\mathrm{pH}$, is converted into $\Delta s$ by a secondary $\mathrm{Na}^{+}$-pumping mechanism-for example, a $\mathrm{Na}^{+} / \mathrm{H}^{+}$-antiporter [49] -as it also takes place in alkaliphilic Bacillus species (for review, see [50]). In order to find out what kind of energy transfer mechanism was used by the cells to initiate operation of the flagellar motor, we investigated the effects of protonophores and some inhibitors.

Bacterial motility was preliminarily initiated by adding either thiosulfate or ascorbate to the suspension of starved motionless cells in the presence of $\mathrm{Na}^{+}$ions. Figure $6 \mathrm{a}, \mathrm{b}$ show the effects of the protonophores carbonyl cyanide m-chlorophenylhydrazone (CCCP) and 2-heptyl-4-hydroxyquinoline $\mathrm{N}$-oxide (HQNO) on T. versutus motility. It can be seen that CCCP had almost no effect, but HQNO increased motility quite strongly. 


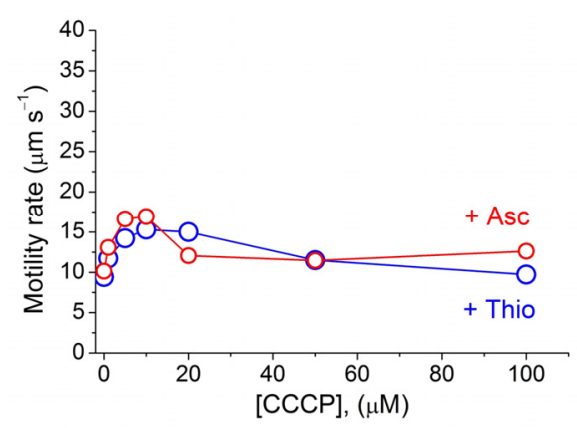

(a)

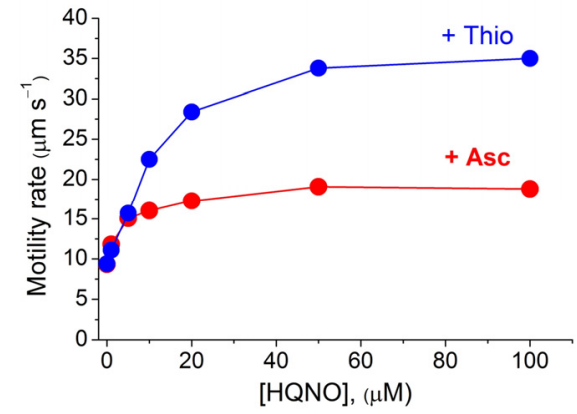

(b)

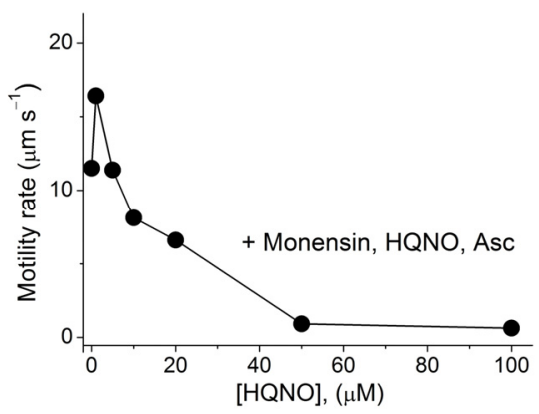

(c)

Figure 6. Effects of protonophores $\mathrm{CCCP}(\mathbf{a})$ and $\mathrm{HQNO}(\mathbf{b})$, and the $\mathrm{Na}^{+} / \mathrm{H}^{+}$ionophore monensin (c), on bacterial cell motility. (a,b) Cell motility was started by the addition of either $1.5 \mathrm{mM}$ thiosulfate (blue curves) or (a-c) $10 \mathrm{mM}$ ascorbate (red curves) in the presence of $10 \mathrm{mM} \mathrm{NaCl}$ (final concentrations indicated); (c) $50 \mu \mathrm{M}$ monensin was added to the cell suspension supplied with $10 \mathrm{mM}$ potassium ascorbate in the presence of $10 \mathrm{mM} \mathrm{NaCl}$ and the protonophore HQNO (black circles).

Apparently, the favorable effect of HQNO on the motility of the studied bacteria may be explained by the decrease in the electric potential $(\Delta \psi)$ on bacterial membranes due to the protonophorous action of HQNO. As we have shown previously, HQNO, in contrast to CCCP, is an effective protonophore at alkaline $\mathrm{pH}$ [29]; this is why HQNO can transport $\mathrm{H}^{+}$from the outer medium to the negatively charged interior of bacteria; as a result, $\Delta \psi$ decreases. This situation may be similar to the state of bacteria with a decrease in energy resources, when cells became motile (Figure 3a). It is likely that, both in the presence of HQNO and with a deficit of energy resources, a decrease in $\Delta \psi$ serves as a signal for the acquisition of motility and the following migration of bacteria to more favorable conditions.

Another possibility arises due to the fact that, according to our data [33], the $\Delta \psi$ level in respiring T. versutus can reach a value of $-228 \mathrm{mV}$, which is higher than in other bacteria and mitochondria. High $\Delta \psi$ is dangerous for biomembranes-especially for mitochondrial membranes and mitochondrial metabolism-as has been shown using planar membranes [51]. It cannot be ruled out that a certain high $\Delta \psi$ level in bacterial membranes may be harmful due to increase in membrane permeability for $\mathrm{Na}^{+}$, which is present at a very high concentration in the medium.

In the presence of the protonophore HQNO, not only does $\Delta \psi$ decrease, but $\Delta p$ dissipates, and should an $\mathrm{H}^{+}$pump be involved in the energization of the flagellar motor, the motor would have to stop. However, this did not happen (Figure 6b); on the contrary, the rate of cell motility increased 2-3.5 times in the presence of HQNO, which excludes the secondary mechanism of energization of the flagellar motor when an $\mathrm{H}^{+}$pump and $\mathrm{Na}^{+} / \mathrm{H}^{+}$antiporter are involved. It should be noted that in the first minutes upon the addition of the respiratory substrate and HQNO to T. versutus cells, when $\Delta \psi$ and $\Delta p$ fall to values close to zero, a 10-fold gradient of sodium ions is generated, corresponding to a very high $\triangle \mathrm{pNa}$ value of $-220--260 \mathrm{mV}$ (see Figure 3A in [29]). The observed scenario most closely matches the direct use of $\Delta s$.

The above effect can be explained by the fact that the protonophore provides an entry of $\mathrm{H}^{+}$counterions into the cell in accordance with the law of electroneutrality, and thereby prevents the electric field from controlling the operation of the $\mathrm{Na}^{+}$pump. As a result, the activity of the primary $\mathrm{Na}^{+}$pump increases, followed by an increase in $\Delta \mathrm{pNa}$ with the simultaneous dissipation of the electric potential on the membrane. The stimulation effect of protonophore uncouplers on $\mathrm{Na}^{+}$pumping has been described for a number of $\Delta s$-generating proteins [52], among which are $\mathrm{Na}^{+}$-pumping $\mathrm{NADH}$-quinone oxidoreductases [53], $\mathrm{Na}^{+}$-ATPases [54-58], recently described $\mathrm{Na}^{+}$-pumping cytochrome oxidase $[28,29]$, and $\mathrm{Na}^{+}$-proteorhodopsins $[59,60]$. Consistent with the above explanation for the effect of HQNO, we showed that in the presence of $\mathrm{HQNO}$, the $\mathrm{Na}^{+} / \mathrm{H}^{+}$antiporter monensin (dissipating transmembrane $\left[\mathrm{Na}^{+}\right]$and $\left[\mathrm{H}^{+}\right]$gradients) abolished the HQNO- 
induced stimulation of the motility rate (Figure 6c). Thus, the obtained data support the direct use of $\Delta s$ generated by the primary $\mathrm{Na}^{+}$pump, which could be represented in T. versutus by the $\mathrm{Na}^{+}$-motive $c b b_{3}$ oxidase and / or a $\mathrm{Na}^{+}$-motive ATPase.

To test possible mediation of ATPase as a generator of $\Delta s$, we used the cells washed to remove sodium and preincubated with or without $20 \mathrm{mM}$ arsenate for a day. The motility of such cells (both in the absence of arsenate when ATPase was functioning, and in the presence of $20 \mathrm{mM}$ arsenate when ATPase was blocked) was successfully triggered by ascorbate in a sodium-dependent mode, and the speed of motility did not depend on the presence of arsenate. These results excluded participation of ATPase in the energization of flagella, and showed that the generation of $\Delta s$ by the $\mathrm{Na}^{+}$-motive cytochrome- $c b b_{3}$ oxidase triggers the $\mathrm{Na}^{+}$-type flagella motor. Thus, in T. versutus, a $\mathrm{Na}^{+}$cycle operates that includes a $\Delta s$ generator $\left(\mathrm{Na}^{+}\right.$-motive cytochrome- $c b b_{3}$ oxidase) and a $\Delta s$ consumer $\left(\mathrm{a} \mathrm{Na}^{+}\right.$-type flagellar motor).

Previously, Chernyak et al. showed that the flagellar motor of marine V. alginolyticus is powered by $\Delta s$ [61]. Later, Atsumi et al. found that, depending on the habitat, $V$. parahaemolyticus can acquire two types of flagellar motor that differ in coupling ions, localization, and functional specialization - namely, laterally located $\mathrm{H}^{+}$-motive flagella, and polar-located $\mathrm{Na}^{+}$-motive flagella [45]. According to our study, the batch-cultured T. versutus strain bears a single polar flagellum, which is clearly a $\mathrm{Na}^{+}$-motive flagellar motor.

To our knowledge, here we have demonstrated for the first time that the activation of the $\Delta s$ generator by protonophores leads to stimulation of the $\Delta s$ consumer (the $\mathrm{Na}^{+}$-motive flagellar motor). In particular, stimulation is manifested to a greater extent in the presence of $\mathrm{HQNO}$, and to a lesser extent in the presence of CCCP, which is consistent with the efficiency of these protonophores at alkaline and weakly acidic/neutral $\mathrm{pH}$, respectively [29]. The reasons why activation of bacterial motility in the presence of protonophores has not been previously described in the literature may be as follows: HQNO inhibits $\mathrm{Na}^{+}-\mathrm{NADH}-$ CoQ-reductase (NQR) [53], the functional operon of which is lacking in the genome of T. versutus. Considering the above, it can be assumed that in bacteria bearing NQR the protonophore-stimulating effect of $\mathrm{HQNO}$ was leveled by its inhibitory counter-effect on $\mathrm{NQR}$ activity $[45,47]$, while CCCP was less effective as a protonophore at alkaline $\mathrm{pH}$.

Being similar in architecture to the known $c b b_{3}$ oxidases, the $\mathrm{Na}^{+}$-motive oxidase has unique properties that open the way for favorable existence of natronophilic T. versutus in soda lakes [37]. Having specific motifs in the amino acid sequence of the catalytic subunit capable of binding $\mathrm{Na}^{+}$ions, this $\mathrm{CO}$ shows a strongly negative redox potential of the cytochrome-c-bearing subunits, which apparently promote energy conversion under alkaline conditions [37]. Based on our previous studies of T. versutus cells, we can deduce the $\Delta s$ value generated on their membranes in $5 \mathrm{~min}$ after substrate addition. The $\Delta s$ is composed of $\Delta \psi(-228 \mathrm{mV})$ [33] and $60 \Delta \mathrm{pNa}(-42 \mathrm{mV})$ [29], resulting in an overall $-270 \mathrm{mV}$. It can be assumed that the previously demonstrated much lower ${ }^{22} \mathrm{Na}^{+}$leakage across membranes in T. versutus compared to non-extremophilic Paracoccus denitrificans (see Figure 3 in [29]) ensures the maintenance of such a high $\Delta s$ value. This high value helps explain how extreme bacteria not only escape depression as a consequence of low $\Delta p$, but flourish and offset the much higher energy costs they incur to survive in severe extreme conditions.

The obtained data may also explain the ecological preferences of $T$. versutus. It is known that these bacteria are confined to living in a narrow zone called the chemocline. The sodium energetic cycle, formed by $\mathrm{Na}^{+}$-motive cytochrome oxidase and $\mathrm{Na}^{+}$-type flagella, could serve as a mechanism by which the bacteria are retained in this zone in the presence of sodium and a highly alkaline $\mathrm{pH}$ of the medium. Obviously, far from the chemocline zone, the concentration of sulfur-containing substrates decreases and, according to our results, activates the bacterial motility providing them with access to areas more rich in nutrients. On the other hand, when bacteria approach the chemocline zone, which is rich in sulfur-containing substrates, the speed of their motility should slow down, leading to the retention of bacterial cells in this zone. 


\section{Materials and Methods}

\subsection{Materials}

Amiloride, monensin, carbonyl cyanide m-chlorophenylhydrazone (CCCP), 2-heptyl4-hydroxyquinoline $\mathrm{N}$-oxide (NQNO), $\mathrm{KCl}$ and $\mathrm{KOH}$ free of sodium were purchased from Sigma-Aldrich (St. Louis, USA); dimethyl sulfoxide (DMSO) was purchased from Merck (Darmstadt, Germany).

\subsection{Bacteria Growth Conditions for the Experiments}

The type strain Thioalkalivibrio versutus AL2 (T. versutus) was cultured in $25 \mathrm{~mL}$ of a "soda" medium at pH 10.2, with thiosulfate as a growth substrate [27], under conditions of limited aeration in $50 \mathrm{~mL}$ Falcon tubes on a Biosan ES-20 rotary shaker (Biosan, Riga, Latvia) at $90 \mathrm{rpm}$ and $30^{\circ} \mathrm{C}$ until the stationary phase of growth. During that time, the tubes were set at an angle of $120^{\circ}$ relative to the horizon. The content of thiosulfate consumed in the nutrient medium was estimated by the cyanolytic method, which allows for individual quantitative determination of thiosulfate, tetrathionate, and trithionate [62].

\subsection{Analysis of Hemes}

The membranes of the grown bacterial cells were isolated as described previously [63] with some modifications [37], and analyzed for heme content. For this purpose, heme was extracted from the isolated cellular membranes, and the following heme analysis was performed using HPLC as described previously [64], with some modifications [65]. Heme was extracted and separated via reversed-phase chromatography on a Diasorb-C16 column $3 \times 250 \mathrm{~mm}$ (Elsico, Moscow, Russia) at a flow rate of $1 \mathrm{~mL} / \mathrm{min}$, with detection at $406 \mathrm{~nm}$ on a PU 4110 chromatograph (Philips Scientific (Pye Unicam), Cambridge, UK). To calibrate the chromatographic column, the elution times of standard heme A and B isolated from bovine heart cytochrome oxidase, and heme $\mathrm{D}$ and $\mathrm{O}$ isolated from $E$. coli, were determined as described previously [65].

\subsection{Selection of Motile Cells}

For experiments on cell motility, the most motile bacterial cells were selected by multiple passages. For this, the stationary cell culture was sedimented in a benchtop Eppendorf centrifuge $5418\left(5000 \mathrm{rpm}, 5 \mathrm{~min}, 20^{\circ} \mathrm{C}\right)$, and a thick bacterial suspension withdrawn from the surface of the pellet (inoculum, $20 \mu \mathrm{L}$ ) was placed in the center of Petri dishes filled with a semi-liquid medium containing $0.3 \%$ agarose and the "soda" medium ( $\mathrm{pH} 10.2)$, supplied with a growth substrate $(2.5 \mathrm{mM}$ thiosulfate) as described previously. One minute after placing the inoculum of the passaged cells in the center of Petri dishes, an inoculum of control cells $(3 \mu \mathrm{L})$ that were not passaged was added (visible as a bright white dot in the center of Petri dishes; Figure 2). To view Petri dishes inoculated with passaged cells only (a total inoculum volume of $23 \mu \mathrm{L}$ ), see Figure S1. Upon inoculation, the agarose plates were left on a flat surface at $20^{\circ} \mathrm{C}$, and after a few hours the cells began to form swimming rings, as shown in Figure 3. The diameter of the swimming rings was measured with a ruler. The cells that ran farthest from the center of the Petri dish were collected and used for the next passage on a fresh Petri dish. After three successive passages, the most motile cells were selected and used in microscopy experiments. Amiloride (an inhibitor of $\mathrm{Na}^{+}$channels) was used as a solution in dimethyl sulfoxide (DMSO). When used on agarose plates, the following concentrations of amiloride were tested: $0.005 \mathrm{mM}, 0.01 \mathrm{mM}$, $0.02 \mathrm{mM}, 0.035 \mathrm{mM}, 0.05 \mathrm{mM}, 0.1 \mathrm{mM}$, and $0.2 \mathrm{mM}$. To achieve the indicated concentrations of amiloride, small aliquots of the stock solution of amiloride in DMSO and, if necessary, DMSO free of amiloride, were added to the cooling agarose medium to maintain a final DMSO concentration of $0.25 \%(v / v)$.

\subsection{Respiratory Activity}

The respiratory activity of the cells was assessed as previously described at $25^{\circ} \mathrm{C}$ [29] by monitoring the oxygen consumption of the cell suspension in a thermostatically con- 
trolled semi-closed measuring chamber with a useful capacity of $0.75 \mathrm{~mL}$. Oxygen consumption was determined polarographically, using a Clark-type electrode (amperometric oxygen sensor) housed in the measuring chamber and connected to an "Expert" millivoltmeter with a corrosometer function (Eco-Expert, Moscow, Russia). At the output, the millivoltmeter was interfaced with a computer, and the resulting digital signals from the millivoltmeter were continuously recorded in the form of a time-dependent graphic chart using the PC software supplied by the manufacturer.

\subsection{Evaluation of Swimming Speed in a Liquid Medium}

The motility speed was evaluated in a Goryaev chamber filled with a liquid medium of the composition specified in the Results section. The motility observations and speed evaluation were performed using an Eclipse E200 microscope (Nikon, Tokyo, Japan) and a stopwatch. The swimming speeds of the cells were measured for at least $40-45$ cells in each experimental condition and then averaged. In experiments to determine the ion dependence of motility, the sodium concentration in the bacterial suspension was varied by adding small aliquots of incubation medium containing $4 \mathrm{M} \mathrm{NaCl}$ and an appropriate volume of $4 \mathrm{M} \mathrm{KCl}$ solution to maintain a constant ionic strength with each new desired concentration of $\mathrm{NaCl}$. The protonophores $\mathrm{CCCP}$ and $\mathrm{HQNO}$, as well as the ionophore monensin, were used as stock solutions in ethanol and added to the bacterial suspension as small aliquots to achieve the required concentrations. The final ethanol concentrations did not exceed $0.5 \%(v / v)$. The effects of each compound-CCCP or HQNO-as well as monensin on the motility rate were determined $1 \mathrm{~min}$ after the addition of various concentrations of these ionophores.

\subsection{Electron Microscopy}

For total electron microscopy, the cells were fixed with paraformaldehyde $(4 \% w / v$ final) for $1 \mathrm{~h}$ at $4{ }^{\circ} \mathrm{C}$, and applied to a copper grid coated with collodium film for $5 \mathrm{~min}$, then stained for $30 \mathrm{~s}$ in $1 \%(w / v)$ uranyl acetate. The preparations were observed on a JEOL 100 transmission electron microscope (JEOL Ltd., Tokyo, Japan).

\section{Conclusions}

Natronophilic T. versutus bacteria are motile and equipped with polar flagella of the $\mathrm{Na}^{+}$type. The energetic strategy of the bacteria when they perform mechanical work such as motility is to use the $\mathrm{Na}^{+}$cycle, which includes operation of the $\mathrm{Na}^{+}$-motive $c b b_{3}$ oxidase and $\mathrm{Na}^{+}$-type flagella. The results are consistent with the hypothesis that $\mathrm{Na}^{+}$-motive motility is an adaptive function in these bacteria that, under conditions of extreme alkalinity and salinity, allows them to stay in a zone enriched with sulfur-containing nutrients.

Supplementary Materials: The following are available online at https:/ / www.mdpi.com/article/ 10.3390 /ijms23041965/s1.

Author Contributions: Conceptualization, validation, M.S.M. and V.P.S.; methodology, software, formal analysis, and investigation, M.S.M., M.B.V. and D.Y.S.; project administration, writingoriginal draft preparation, M.S.M.; writing—review and editing, funding acquisition, M.S.M. and V.P.S. All authors have read and agreed to the published version of the manuscript.

Funding: The completion of this study was supported by the Russian Foundation for Basic Research (grant 20-04-01105).

Institutional Review Board Statement: This study did not involve humans or animals.

Informed Consent Statement: Not applicable.

Acknowledgments: The authors are grateful to Svetlana I. Galkina for the kind donation of amiloride used for the experiments, and to Irina Y. Fokina for critically reading the manuscript.

Conflicts of Interest: The authors declare no conflict of interest. The funding organization had no role in the design, execution, interpretation, or writing of the study. 


\section{References}

1. Merino, N.; Aronson, H.S.; Bojanova, D.P.; Feyhl-Buska, J.; Wong, M.L.; Zhang, S.; Giovannelli, D. Living at the extremes: Extremophiles and the limits of life in a planetary context. Front. Microbiol. 2019, 10, 780. [CrossRef]

2. Mehda, S.; Muñoz-Martín, M.Á.; Oustani, M.; Hamdi-Aïssa, B.; Perona, E.; Mateo, P. Lithic cyanobacterial communities in the polyextreme Sahara Desert: Implications for the search for the limits of life. Environ. Microbiol. 2021. [CrossRef]

3. González, J.M.; Kato, C.; Horikoshi, K. Thermococcus peptonophilus sp. nov., a fast-growing, extremely thermophilic archaebacterium isolated from deep-sea hydrothermal vents. Arch. Microbiol. 1995, 164, 159-164. [CrossRef] [PubMed]

4. Krulwich, T.A.; Sachs, G.; Padan, E. Molecular aspects of bacterial pH sensing and homeostasis. Nat. Rev. Microbiol. 2011, 9, 330-343. [CrossRef] [PubMed]

5. Stan-Lotter, H.; Fendrihan, S. Halophilic archaea: Life with desiccation, radiation and oligotrophy over geological times. Life 2015, 5, 1487-1496. [CrossRef]

6. Gavrilov, S.; Podosokorskaya, O.; Alexeev, D.; Merkel, A.; Khomyakova, M.; Muntyan, M.; Altukhov, I.; Butenko, I.; BonchOsmolovskaya, E.; Govorun, V.; et al. Respiratory pathways reconstructed by multi-omics analysis in Melioribacter roseus, residing in a deep thermal aquifer of the West-Siberian megabasin. Front. Microbiol. 2017, 8, 1228. [CrossRef] [PubMed]

7. Sorokin, D.Y.; Muntyan, M.S.; Toshchakov, S.V.; Korzhenkov, A.; Kublanov, I.V. Phenotypic and genomic properties of a novel deep-lineage haloalkaliphilic member of the phylum Balneolaeota from soda lakes possessing $\mathrm{Na}^{+}$-translocating proteorhodopsin. Front. Microbiol. 2018, 9, 2672. [CrossRef] [PubMed]

8. Daebeler, A.; Kitzinger, K.; Koch, H.; Herbold, C.W.; Steinfeder, M.; Schwarz, J.; Zechmeister, T.; Karst, S.M.; Albertsen, M.; Nielsen, P.H.; et al. Exploring the upper $\mathrm{pH}$ limits of nitrite oxidation: Diversity, ecophysiology, and adaptive traits of haloalkalitolerant Nitrospira. ISME J. 2020, 14, 2967-2979. [CrossRef]

9. Calisto, F.; Sousa, F.M.; Sena, F.V.; Refojo, P.N.; Pereira, M.M. Mechanisms of Energy Transduction by Charge Translocating Membrane Proteins. Chem. Rev. 2021, 121, 1804-1844. [CrossRef]

10. Kell, D.B. A protet-based, protonic charge transfer model of energy coupling in oxidative and photosynthetic phosphorylation. Adv. Microb. Physiol. 2021, 78, 1-177. [CrossRef]

11. Zeng, Y.; Chen, X.; Madsen, A.M.; Zervas, A.; Nielsen, T.K.; Andrei, A.S.; Lund-Hansen, L.C.; Liu, Y.; Hansen, L.H. Potential rhodopsin- and bacteriochlorophyll-based dual phototrophy in a high Arctic glacier. mBio 2020, 11, e02641-20. [CrossRef]

12. Xue, Q.; Zhao, D.; Zhang, S.; Zhou, H.; Zuo, Z.; Zhou, J.; Li, M.; Xiang, H. Highly integrated adaptive mechanisms in Spiribacter halalkaliphilus, a bacterium abundant in Chinese soda-saline lakes. Environ. Microbiol. 2021, 23, 6463-6482. [CrossRef] [PubMed]

13. Mevada, V.A.; Beladiya, U.H.; Gandhi, H.R.; Mangrola, A.V.; Patel, R.K. Alkalophiles: Environmental Distribution, Taxonomy, Physiology, Bioenergetics, Survival Mechanism, and Enzymes. In Physiology, Genomics, and Biotechnological Applications of Extremophiles; Gunjal, A.B., Thombre, R., Parray, J.A., Eds.; IGI Global: Hershey, PA, USA, 2022; pp. 35-64. [CrossRef]

14. Adams, M.W.; Perler, F.B.; Kelly, R.M. Extremozymes: Expanding the limits of biocatalysis. Biotechnology 1995, 13, 662-668. [CrossRef] [PubMed]

15. Bankar, A.; Patil, S.; Shinde, M.; Kowligi, B. Potential of microbial extremophiles for biotechnological applications: An overview. In Microbial Extremozymes. Novel Sources and Industrial Applications; Kuddus, M., Ed.; Academic Press: Cambridge, MA, USA, 2022; pp. 89-110. [CrossRef]

16. Dumorné, K.; Córdova, D.C.; Astorga-Eló, M.; Renganathan, P. Extremozymes: A potential source for industrial applications. J Microbiol. Biotechnol. 2017, 27, 649-659. [CrossRef] [PubMed]

17. Banciu, H.L.; Muntyan, M.S. Adaptive strategies in the double-extremophilic prokaryotes inhabiting soda lakes. Curr. Opin. Microbiol. 2015, 25, 73-79. [CrossRef] [PubMed]

18. Gorlenko, V.M.; Buryukhaev, S.P.; Matyugina, E.B.; Borzenko, S.V.; Namsaraev, Z.B.; Bryantseva, I.A.; Boldareva, E.N.; Sorokin, D.Y.; Namsaraev, B.B. Microbial communities of the stratified soda Lake Doroninskoe (Transbaikal region). Microbiology 2010, 79, 390-401. [CrossRef]

19. Yang, J.; Jiang, H.; Dong, H.; Wu, G.; Hou, W.; Zhao, W.; Sun, Y.; Lai, Z. Abundance and diversity of sulfur-oxidizing bacteria along a salinity gradient in four Qinghai-Tibetan lakes, China. Geomicrobiol. J. 2013, 30, 851-860. [CrossRef]

20. Zakharyuk, A.G.; Kozyreva, L.P.; Khijniak, T.V.; Namsaraev, B.B.; Shcherbakova, V.A. Desulfonatronum zhilinae sp. nov., a novel haloalkaliphilic sulfate-reducing bacterium from soda Lake Alginskoe, Trans-Baikal Region, Russia. Extremophiles 2015, 19, 673-680. [CrossRef]

21. Sorokin, D.Y.; Banciu, H.L.; Muyzer, G. Functional microbiology of soda lakes. Curr. Opin. Microbiol. 2015, 25, 88-96. [CrossRef]

22. Burganskaya, E.I.; Bryantseva, I.A.; Gaisin, V.A.; Grouzdev, D.S.; Rysina, M.S.; Barkhutova, D.D.; Baslerov, R.V.; Gorlenko, V.M.; Kuznetsov, B.B. Benthic phototrophic community from Kiran soda lake, south-eastern Siberia. Extremophiles 2018, 22, 211-220. [CrossRef]

23. Kulkarni, S.; Dhakar, K.; Joshi, A. Alkaliphiles: Diversity and bioprospection. In Microbial Diversity in the Genomic Era; Academic Press: Cambridge, MA, USA, 2019; pp. 239-263. [CrossRef]

24. Lavrentyeva, E.V.; Erdyneeva, E.B.; Banzaraktsaeva, T.G.; Kotsyurbenko, O.R.; Baturina, O.A.; Khakhinov, V.V.; Kozyreva, L.P. Prokaryotic diversity in the biotopes of the gudzhirganskoe Saline Lake (Barguzin Valley, Russia). Microbiology 2020, 89, 359-368. [CrossRef]

25. Chakraborty, J.; Rajput, V.; Sapkale, V.; Kamble, S.; Dharne, M. Spatio-temporal resolution of taxonomic and functional microbiome of Lonar soda lake of India reveals metabolic potential for bioremediation. Chemosphere 2021, 264, 128574. [CrossRef] 
26. Sorokin, D.Y.; Banciu, H.; Robertson, L.A.; Kuenen, J.G.; Muntyan, M.S.; Muyzer, G. Halophilic and haloalkaliphilic sulfuroxidizing bacteria. In The Prokaryotes: Prokaryotic Physiology and Biochemistry; Rosenberg, E., DeLong, E., Lory, S., Stackebrandt, E., Thompson, F., Eds.; Springer: Berlin/Heidelberg, Germany, 2013; pp. 529-554. [CrossRef]

27. Sorokin, D.Y.; Lysenko, A.M.; Mityushina, L.L.; Tourova, T.P.; Jones, B.E.; Rainey, F.A.; Robertson, L.A.; Kuenen, G.J. Thioalkalimicrobium aerophilum gen. nov., sp. nov. and Thioalkalimicrobium sibericum sp. nov., and Thioalkalivibrio versutus gen. nov., sp. nov., Thioalkalivibrio nitratis sp. nov., novel and Thioalkalivibrio denitrificancs sp. nov., novel obligately alkaliphilic and obligately chemolithoautotrophic sulfur-oxidizing bacteria from soda lakes. Int. J. Syst. Evol. Microbiol. 2001, 51, 565-580. [CrossRef] [PubMed]

28. Grischuk, Y.V.; Muntyan, M.S.; Popova, I.V.; Sorokin, D.Y. Ion transport coupled to terminal oxidase functioning in the extremely alkaliphilic halotolerant bacterium Thioalkalivibrio. Biochemistry 2003, 68, 385-390. [CrossRef]

29. Muntyan, M.S.; Cherepanov, D.A.; Malinen, A.M.; Bloch, D.A.; Sorokin, D.Y.; Severina, I.I.; Ivashina, T.V.; Lahti, R.; Muyzer, G.; Skulachev, V.P. Cytochrome $c b b_{3}$ of Thioalkalivibrio is a $\mathrm{Na}^{+}$-pumping cytochrome oxidase. Proc. Natl. Acad. Sci. USA 2015, 112, 7695-7700. [CrossRef]

30. Skulachev, V.P. Sodium bioenergetics. Trends Biochem. Sci. 1984, 9, 483-485. [CrossRef]

31. Skulachev, V.P. Membrane-linked energy transductions. Bioenergetic functions of sodium: $\mathrm{H}^{+}$is not unique as a coupling ion. Eur. J. Biochem. 1985, 151, 199-208. [CrossRef] [PubMed]

32. Skulachev, V.P. The laws of cell energetics. Eur. J. Biochem. 1992, 208, 203-209. [CrossRef]

33. Muntyan, M.S.; Morozov, D.A.; Klishin, S.S.; Khitrin, N.V.; Kolomijtseva, G.Y. Evaluation of the electrical potential on the membrane of the extremely alkaliphilic bacterium Thioalkalivibrio. Biochemistry 2012, 77, 917-924. [CrossRef] [PubMed]

34. Guffanti, A.A.; Krulwich, T.A. Oxidative phosphorylation by ADP + P(i)-loaded membrane vesicles of alkaliphilic Bacillus firmus OF4. J. Biol. Chem. 1994, 269, 21576-21582. [CrossRef]

35. Slonczewski, J.L.; Fujisawa, M.; Dopson, M.; Krulwich, T.A. Cytoplasmic pH measurement and homeostasis in bacteria and archaea. Adv. Microb. Physiol. 2009, 55, 1-317. [CrossRef]

36. Skulachev, V.P. Energetics of Biological Membranes; Severin, S.E., Ed.; Nauka: Moscow, Russia, 1989; 564p.

37. Muntyan, M.S.; Morozov, D.A.; Leonova, Y.F.; Ovchinnikova, T.V. Identification of $\mathrm{Na}^{+}$-pumping Cytochrome Oxidase in the Membranes of Extremely Alkaliphilic Thioalkalivibrio Bacteria. Biochemistry 2020, 85, 1631-1639. [CrossRef] [PubMed]

38. Muyzer, G.; Sorokin, D.Y.; Mavromatis, K.; Lapidus, A.; Foster, B.; Sun, H.; Ivanova, N.; Pati, A.; D’haeseleer, P.; Woyke, T.; et al Complete genome sequence of Thioalkalivibrio sp. K90mix. Stand. Genomic. Sci. 2011, 5, 341-355. [CrossRef] [PubMed]

39. Muntyan, M.S.; Morozov, D.A. Motility of natronophilic bacteria Thioalkalivibrio versutus. Nor. J. Dev. Int. Sci. 2016, 1, 17-19.

40. Banciu, H.L.; Sorokin, D.Y.; Tourova, T.P.; Galinski, E.A.; Muntyan, M.S.; Kuenen, J.G.; Muyzer, G. Influence of salts and pH on growth and activity of a novel facultatively alkaliphilic, extremely salt-tolerant, obligately chemolithoautotrophic sufur-oxidizing Gammaproteobacterium Thioalkalibacter halophilus gen. nov., sp. nov. from South-Western Siberian soda lakes. Extremophiles 2008, 12, 391-404. [CrossRef] [PubMed]

41. Sorokin, D.Y.; Muntyan, M.S.; Panteleeva, A.N.; Muyzer, G. Thioalkalivibrio sulfidiphilus sp. nov., a haloalkaliphilic, sulfur-oxidizing gammaproteobacterium from alkaline habitats. Int. J. Syst. Evol. Microbiol. 2012, 62, 1884-1889. [CrossRef] [PubMed]

42. Labelle, E.F.; Woodard, P.L.; Cragoe, E.J. The interaction of amiloride analogues with the $\mathrm{Na}^{+} / \mathrm{H}^{+}$exchanger in kidney medulla microsomes. Biochim. Biophys. Acta 1984, 778, 129-138. [CrossRef]

43. Sugiyama, S.; Cragoe, E.J.; Imae, Y. Amiloride, a specific inhibitor for the $\mathrm{Na}^{+}$-driven flagellar motors of alkalophilic Bacillus. J. Biol. Chem. 1988, 263, 8215-8219. [CrossRef]

44. Atsumi, T.; Sugiyama, S.; Cragoe, E.J.; Imae, Y. Specific inhibition of the $\mathrm{Na}^{+}$-driven flagellar motors of alkalophilic Bacillus strains by the amiloride analog phenamil. J. Bacteriol. 1990, 172, 1634-1639. [CrossRef]

45. Atsumi, T.; McCartert, L.; Imae, Y. Polar and lateral flagellar motors of marine Vibrio are driven by different ion-motive forces. Nature 1992, 355, 182-184. [CrossRef]

46. Imae, Y.; Atsumi, T. Na ${ }^{+}$-driven bacterial flagellar motors. J. Bioenerg. Biomembr. 1989, 21, 705-716. [CrossRef] [PubMed]

47. Kojima, S.; Yamamoto, K.; Kawagishi, I.; Homma, M. The polar flagellar motor of Vibrio cholerae is driven by an $\mathrm{Na}^{+}$motive force. J. Bacteriol. 1999, 181, 1927-1930. [CrossRef] [PubMed]

48. Atsumi, T.; Maekawa, Y.; Tokuda, H.; Imae, Y. Amiloride at pH 7.0 inhibits the $\mathrm{Na}^{+}$-driven flagellar motors of Vibrio alginolyticus but allows cell growth. FEBS Lett. 1992, 314, 114-116. [CrossRef]

49. Kawagishi, I.; Maekawa, Y.; Atsumi, T.; Homma, M.; Imae, Y. Isolation of the polar and lateral flagellum-defective mutants in Vibrio alginolyticus and identification of their flagellar driving energy sources. J. Bacteriol. 1995, 177, 5158-5160. [CrossRef]

50. Muntyan, M.S.; Popova, I.V.; Bloch, D.A.; Skripnikova, E.V.; Ustiyan, V.S. Energetics of alkalophilic representatives of the genus Bacillus. Biochemistry 2005, 70, 137-142. [CrossRef]

51. Rupprecht, A.; Sokolenko, E.A.; Beck, V.; Ninnemann, O.; Jaburek, M.; Trimbuch, T.; Klishin, S.S.; Jezek, P.; Skulachev, V.P.; Pohl, E.E. Role of the transmembrane potential in the membrane proton leak. Biophys. J. 2010, 98, 1503-1511. [CrossRef]

52. Dimroth, P. Primary sodium ion translocating enzymes. Biochim. Biophys. Acta 1997, 1318, 11-51. [CrossRef]

53. Tokuda, H.; Unemoto, T. $\mathrm{Na}^{+}$is translocated at NADH: Quinone oxidoreductase segment in the respiratory chain of Vibrio alginolyticus. J. Biol. Chem. 1984, 259, 7785-7790. [CrossRef]

54. Laubinger, W.; Dimroth, P. Characterization of the ATP synthase of Propionigenium modestum as a primary sodium pump. Biochemistry 1988, 27, 7531-7537. [CrossRef] 
55. Reidlinger, J.; Müller, V. Purification of ATP synthase from Acetobacterium woodii and identification as a Na ${ }^{+}$-translocating $\mathrm{F}_{1} \mathrm{~F}_{\mathrm{O}}$-type enzyme. Eur. J. Biochem. 1994, 223, 275-283. [CrossRef]

56. Murata, T.; Takase, K.; Yamato, I.; Igarashi, K.; Kakinuma, Y. Purification and reconstitution of $\mathrm{Na}^{+}$-translocating vacuolar ATPase from Enterococcus hirae. J. Biol. Chem. 1997, 272, 24885-24890. [CrossRef] [PubMed]

57. Balnokin, Y.V.; Popova, L.G.; Andreev, I.M. Electrogenicity of the $\mathrm{Na}^{+}$-ATPase from the marine microalga Tetraselmis (Platymonas) viridis and associated $\mathrm{H}^{+}$countertransport. FEBS Lett. 1999, 462, 402-406. [CrossRef]

58. Popova, L.G.; Kornilova, A.G.; Shumkova, G.A.; Andreev, I.M.; Balnokin, Y.V. Na ${ }^{+}$-transporting ATPase in the plasma membrane of halotolerant microalga Dunaliella maritima operates as a $\mathrm{Na}^{+}$uniporter. Russ. J. Plant Physiol. 2006, 53, 474-480. [CrossRef]

59. Inoue, K.; Ono, H.; Abe-Yoshizumi, R.; Yoshizawa, S.; Ito, H.; Kogure, K.; Kandori, H. A light-driven sodium ion pump in marine bacteria. Nat. Commun. 2013, 4, 110. [CrossRef]

60. Mamedov, M.D.; Mamedov, A.M.; Bertsova, Y.V.; Bogachev, A.V. A single mutation converts bacterial $\mathrm{Na}^{+}$-transporting rhodopsin into an $\mathrm{H}^{+}$transporter. FEBS Lett. 2016, 590, 2827-2835. [CrossRef]

61. Chernyak, B.V.; Dibrov, P.A.; Glagolev, A.N.; Sherman, M.Y.; Skulachev, V.P. A novel type of energetics in a marine alkali-tolerant bacterium: $\triangle$ pNa-driven motility and sodium cycle. FEBS Lett. 1983, 164, 38-42. [CrossRef]

62. Kelly, D.P.; Chambers, L.A.; Trudinger, P.A. Cyanolysis and spectrophotometric estimation of trithionate in mixture with thiosulphate and tetrathionate. Anal. Chem. 1969, 41, 898-901. [CrossRef]

63. Muntyan, M.S.; Skripnikova, E.V. Two types of terminal oxidase in alkalotolerant Bacillus FTU. Biochim. Biophys. Acta 1993, 1143, 142-146. [CrossRef]

64. Sone, N.; Fujiwara, Y. Effects of Aeration during Growth of Bacillus stearothermophilus on Proton Pumping Activity and Change of Terminal Oxidases. J. Biochem. 1991, 110, 1016-1021. [CrossRef]

65. Muntyan, M.S.; Ustiyan, V.S.; Viryasov, M.B.; Skulachev, V.P. Terminal Oxidases of the $b b$ - and caa $a_{3}$-Types in Bacillus sp. FTU. Biochem. Biophys. Res. Commun. 1995, 207, 55-61. [CrossRef] 